\title{
Reactivity of sewage sludge, RDF, and straw chars towards NO
}

Ulusoy, Burak; Wu, Hao; Lin, Weigang; Karlström, Oskar; Li, Songgeng; Song, Wenli; Glarborg, Peter; Dam-Johansen, Kim

\section{Published in:}

Fuel

Link to article, DOI:

10.1016/j.fuel.2018.08.164

Publication date:

2019

Document Version

Peer reviewed version

Link back to DTU Orbit

Citation (APA):

Ulusoy, B., Wu, H., Lin, W., Karlström, O., Li, S., Song, W., Glarborg, P., \& Dam-Johansen, K. (2019). Reactivity of sewage sludge, RDF, and straw chars towards NO. Fuel, 236, 297-305.

https://doi.org/10.1016/j.fuel.2018.08.164

\section{General rights}

Copyright and moral rights for the publications made accessible in the public portal are retained by the authors and/or other copyright owners and it is a condition of accessing publications that users recognise and abide by the legal requirements associated with these rights.

- Users may download and print one copy of any publication from the public portal for the purpose of private study or research.

- You may not further distribute the material or use it for any profit-making activity or commercial gain

- You may freely distribute the URL identifying the publication in the public portal

If you believe that this document breaches copyright please contact us providing details, and we will remove access to the work immediately and investigate your claim 


\section{Reactivity of sewage sludge, RDF, and straw chars}

\section{towards NO}

Burak Ulusoy ${ }^{1,2}$, Hao Wu ${ }^{1 *}$, Weigang Lin ${ }^{1,5}$, Oskar Karlström ${ }^{3}$, Songgeng Li $^{4,5}$, Wenli Song ${ }^{4,5}$, Peter Glarborg ${ }^{1}$, Kim Dam-Johansen ${ }^{1}$

1: Department of Chemical and Biochemical Engineering, Technical University of Denmark, Søltofts Plads 229, 2800 Kgs. Lyngby, Denmark

2: Sino-Danish Centre for Education and Research, Beijing, China

3: Johan Gadolin Process Chemistry Centre, Åbo Akademi University, Finland

4: State Key Laboratory of Multiphase Complex Systems, Institute of Process Engineering, Chinese

Academy of Sciences, Beijing 100190, China

5: Sino-Danish College, University of Chinese Academy of Sciences, Beijing 100049, China

*Corresponding author e-mail id: haw@kt.dtu.dk, Department of Chemical and Biochemical Engineering, Technical University of Denmark, Søltofts Plads 229, 2800 Kgs. Lyngby, Denmark

Revised manuscript submitted to Fuel, 24-08-2018

The figures are presented in greyscale, making color imaging unnecessary 
1 Abstract: The reaction of NO with chars of sewage sludge, refuse derived fuel (RDF), and straw was

2 investigated in a fixed bed reactor at temperatures from 800 to $900^{\circ} \mathrm{C}$ and NO inlet concentrations from

3400 to 1500 ppmv. The effect of ash forming elements in the chars was examined by comparing the

4 reactivity of raw and demineralized chars. Compared to straw char, the reaction rates of sewage sludge

5 and RDF char, at $800^{\circ} \mathrm{C}$ and $400 \mathrm{ppmv}$ inlet $\mathrm{NO}$, was an order of magnitude and a factor of six higher,

6 respectively. The very high reactivity of the two waste chars was attributed to the catalytic effect of their

7 large content of calcium and iron. A simple first order globalized rate expression was employed to describe

8 the reactivity of waste chars toward NO, which predicted reasonably well the the conversion of char

9 nitrogen to NO during char combustion at $800^{\circ} \mathrm{C}$ in $10 \% \mathrm{O}_{2}$. A comparison with literature data revealed

10 a higher reactivity of the waste chars towards NO compared to that of coal and biomass chars. The results

11 in this work provide a simple and validated rate expression to simulate waste char-NO reaction in boilers,

12 and moreover facilitate a potential utilization of waste chars as primary or secondary measures for NO

13 reduction.

14 Keywords: NO reduction; char reactivity; waste combustion; sewage sludge; refuse derived fuel 


\section{Introduction}

16 Waste fuels are increasingly used in utility and industrial boilers to reduce fuel costs and avoid

17 landfilling [1]. Minimizing $\mathrm{NO}_{\mathrm{x}}$ emissions from waste combustion is important due to the harmful environmental impact and strict emission limits. Two widely used waste combustion technologies are fluidized bed combustion and grate-firing. In both processes, the NO primarily stems from the fuel bound nitrogen, either through volatile or char nitrogen oxidation [2], while the contribution of thermal and

21 prompt NO is small or negligible [3-5]. Once formed, NO may be reduced through homogeneous 22 reactions or by heterogeneous reduction over char [6]. While the gaseous chemistry of NO is fairly well 23 established [2,7], the reaction between char and NO is less understood. Studies show that in comparison 24 to coal, biomass chars generally exhibit a higher reactivity towards NO reduction, partly due to higher 25 contents of potassium [8], sodium [9], calcium, and iron [10], and possibly due to more favorable surface

26 properties, e.g., surface area and pore size distribution [11]. The simultaneous formation and reduction of 27 NO during char combustion is summarized in R1-R9 $[12,13]$. The sequence of NO adsorption and 28 subsequent reduction over char catalysed by ash forming element, M, is illustrated by R3-R9. Here, (-CX) 29 denotes a carbon surface complex of either nitrogen or oxygen, while (-C) is a free carbon active site. The 30 presence of $\mathrm{CO}$ has been shown to promote the reduction of NO, presumably by homogeneous reaction 31 with NO catalysed by char, demonstrated by the non-elementary R6.

$$
\begin{array}{rllr}
\mathrm{O}_{2}+(-\mathrm{C})+(-\mathrm{CN}) & \rightarrow & (-\mathrm{CO})+(-\mathrm{CNO}) & \mathrm{R} 1 \\
(-\mathrm{CNO}) & \rightarrow & \mathrm{NO}+(-\mathrm{C}) & \mathrm{R} 2 \\
\mathrm{NO}+2(-\mathrm{C}) & \rightarrow & (-\mathrm{CO})+(-\mathrm{CN}) & \mathrm{R} 3 \\
2(-\mathrm{CN}) & \rightarrow & \mathrm{N}_{2}+2(-\mathrm{C}) & \mathrm{R} 4 \\
(-\mathrm{CN})+\mathrm{NO} & \rightarrow & \mathrm{N}_{2}+(-\mathrm{CO}) & \mathrm{R} 5 \\
2 \mathrm{NO}+2 \mathrm{CO} & \rightarrow & \mathrm{N}_{2}+2 \mathrm{CO} & \mathrm{R} 6 \\
\left(-\mathrm{M}_{\mathrm{x}} \mathrm{O}_{\mathrm{y}}\right)+(-\mathrm{C})+\mathrm{NO} & \rightarrow & \left(-\mathrm{M}_{\mathrm{x}} \mathrm{O}_{\mathrm{y}}\right)+(-\mathrm{CN}) & \mathrm{R} 7
\end{array}
$$




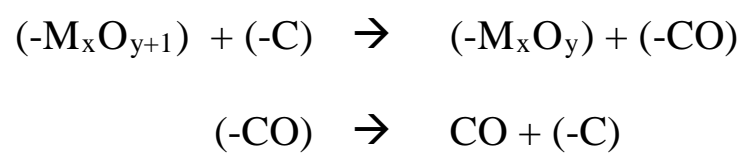

The reaction mechanism involves both catalytic and non-catalytic reaction steps. It indicates that larger contents of surface nitrogen and catalytic inorganic element would lead to a higher NO reduction reactivity. Waste fuels often have both high nitrogen and inorganic element content in the unreacted char. Consequently, these chars could be expected to be very reactive towards NO reduction; however, this has to the knowledge of the authors not been examined.

The objective of the present work is to investigate the reduction of NO over sewage sludge, refuse derived fuel (RDF), and straw chars. The chars of raw and demineralized fuels were prepared in a 40 horizontal oven and subsequently subjected to surface property and chemical composition

41 characterization. NO reduction experiments were performed in a fixed bed reactor to investigate the 42 reactivity of different chars towards NO. Based on the experiments, simple rate expressions that are 43 applicable in large-scale simulations were provided for modelling the NO-char reduction reaction in 44 combustion. Apart from providing an improved fundamental understanding of the char nitrogen to NO conversion and char-NO reduction reaction, the outcome of this study may facilitate the use of chars in $46 \quad$ NO reduction from boilers.

\section{Experimental}

\section{$\underline{2.1 \text { Fuels and their demineralization }}$}

50 Two waste based fuels, sewage sludge (SSL) and RDF, and one biomass, straw (S), were investigated.

51 A previously reported demineralization method [13,14] was adopted in this study. The fuels were ground 52 and sieved to a size fraction of 212-1000 $\mu \mathrm{m}$ and subsequently suspended in $500 \mathrm{~mL} \mathrm{HNO}_{3}$ (Sigma 53 Aldrich, CAS number: 7697-37-2) solution at a $\mathrm{pH}$ value of 2 and heated to $60^{\circ} \mathrm{C}$. In the sewage sludge 54 extraction, the $\mathrm{pH}$ increased significantly, wherefore $\mathrm{HNO}_{3}$ was intermittently added to maintain a $\mathrm{pH}$ of 
2. The leaching was performed for one hour at $60^{\circ} \mathrm{C}$ under stirring at $750 \mathrm{rpm}$. After one hour, the liquid was removed, and the process repeated. Then, the demineralized fuels were filtered with $250 \mathrm{~mL}$ deionized water until the permeate $\mathrm{pH}$ was approximately 6.0. The obtained demineralized fuels were dried at $105^{\circ} \mathrm{C}$ for one day. Notably, RDF was not demineralized due to the limited amount of available sample.

\subsection{Char preparation}

Chars from raw and demineralized fuels were produced in a horizontal oven at $800^{\circ} \mathrm{C}$ under a $\mathrm{N}_{2}$ flow of $2.5 \mathrm{NL} / \mathrm{min}$. The oven was preheated to $800^{\circ} \mathrm{C}$, after which approximately $15 \mathrm{~g}$ of sample was rapidly pushed into the oven and pyrolyzed for 10 minutes. Following this, the sample was quickly moved to a water cooled section to ensure prompt cooling to a temperature of $\sim 150^{\circ} \mathrm{C}$. Then, the sample was withdrawn from the reactor and collected. The char yield was determined from the initial and final sample mass.

\section{$\underline{2.3 \text { Fixed bed reactor combustion and NO reduction }}$}

Figure 1 presents the quartz fixed bed reactor used for combustion and NO reduction experiments. Three independent heating elements ensured a uniform temperature in the reactor. A thermocouple, located 0.5 cm below the porous plate, measured the reaction temperature. A solid feeding device allowed the admission of samples at the desired temperature and gas phase composition in the reactor. In the experiments, $1.75 \mathrm{~g}$ quartz sand pre-treated at $800^{\circ} \mathrm{C}$ with a size of $250-355 \mu \mathrm{m}$ was added together with the char samples to ensure plug flow through the bed and facilitate the sample admission. Blank tests revealed that the thermally treated sand exhibited no reactivity towards NO reduction. Reduction experiments were carried out at three NO inlet concentrations [400,800,1500 ppmv] and temperatures $\left[800,850,900^{\circ} \mathrm{C}\right]$ using $20-50 \mathrm{mg}$ char with a size of $125-180 \mu \mathrm{m}$ to minimize mass transfer limitations and avoid issues in feeding fine particles. To extract kinetic information, the mass of sewage sludge and RDF char was reduced to avoid complete conversion of $\mathrm{NO}$ to $\mathrm{N}_{2}$. Additional combustion experiments using $20 \mathrm{mg}, 125-180 \mu \mathrm{m}$ char were carried out at $800^{\circ} \mathrm{C}$ in $10 \% \mathrm{O}_{2}$. The total volumetric flow rate was $1 \mathrm{NL} / \mathrm{min}$ in both combustion and NO reduction experiments, with the balance being made up by $\mathrm{N}_{2}$. 
80 Moreover, the composition of the dry flue gas was continuously monitored by a series of on-line gas

81 analysers (NGA2000, Fischer-Rosemount); $\mathrm{CO}$ and $\mathrm{CO}_{2}$ were measured by infrared-absorption, $\mathrm{O}_{2}$ by a

82 paramagnetic detector, and NO by an ultraviolet analyser. In addition, the nitrogen combustion product

83 distribution was determined by a Fourier Transform Infrared Spectrometer (FTIR) (Multigas 2030 FTIR,

84 MKS instruments).

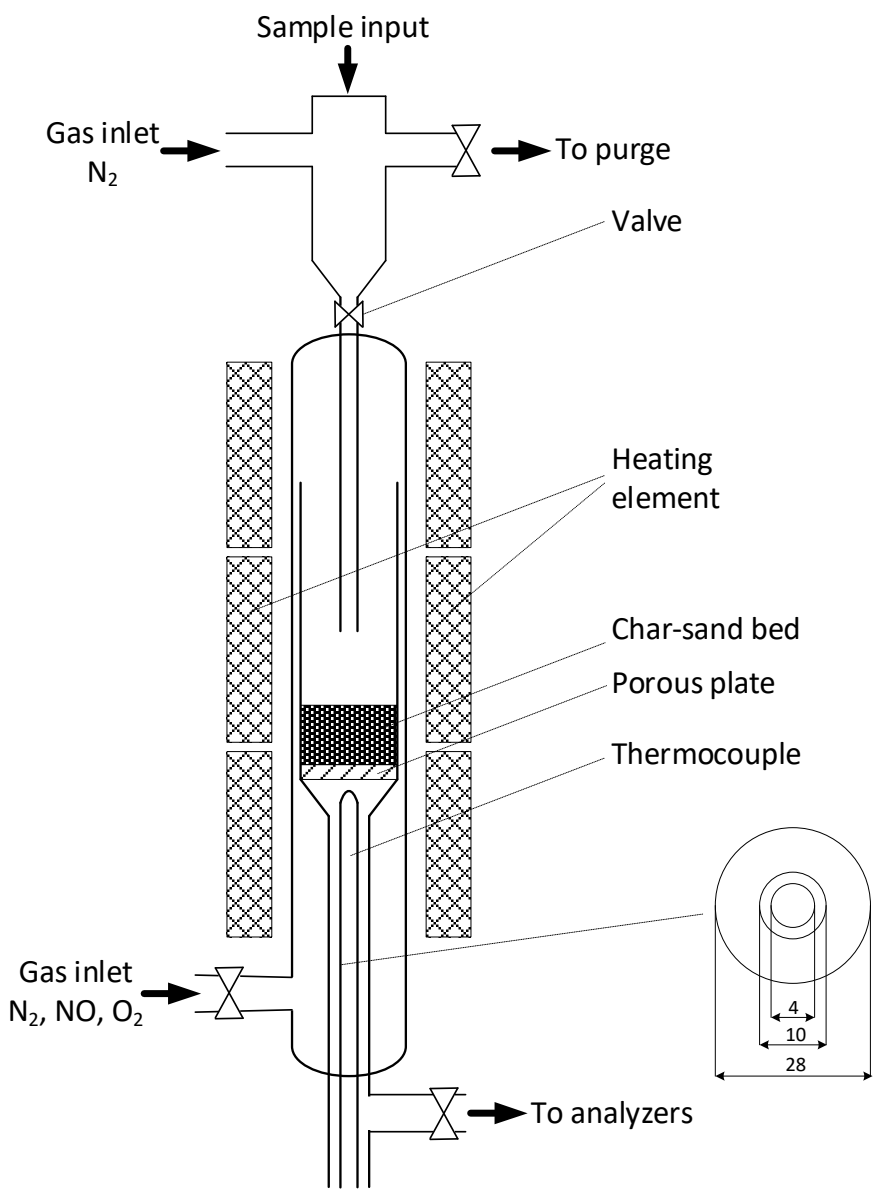

Figure 1: Schematic illustration of the fixed bed reactor.

87 A typical plot of the NO concentration versus time, depicting the complete steps in the reduction

88 experiments, is shown in Figure 2. Each experiment involved four steps (S1-S4), NO signal stabilization

89 (S1), char introduction and NO reduction (S2), NO cutoff and residual char combustion in $10 \mathrm{vol}_{2} \mathrm{O}_{2}$

90 forming a NO concentration peak (S3), and NO signal stabilization (S4). The experiment was stopped 
91 when the NO concentration in S4 equaled that in S1. Little to no reduction of NO was observed over pure

92 fuel ash.

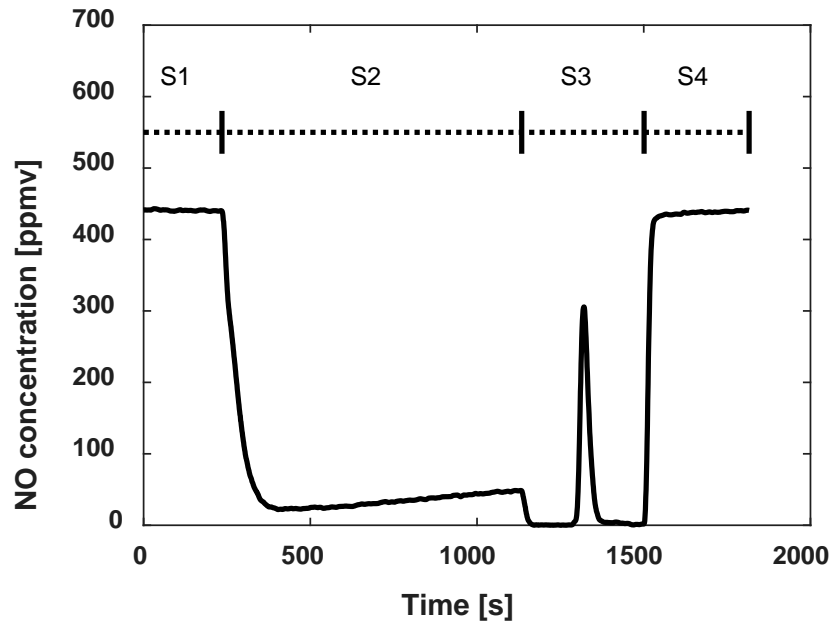

94 Figure 2: Example of a NO versus time curve, illustrating the steps during a reduction experiment. S1:

95 stabilization of the NO signal, S2: introduction of char and NO reduction commences, S3: NO feeding is

96 stopped, and $10 \mathrm{vol} \% \mathrm{O}_{2}$ is introduced to burn residual char, and S4: stabilization of NO signal. The

97 reduction was carried out at $800^{\circ} \mathrm{C}$ with an inlet concentration of $400 \mathrm{ppm}$ NO using straw char.

98 The influence of external and internal mass transfer limitations were assessed based on the Maer and

99 Weisz-Prater criteria [15], respectively. The results are provided in the supplemental material (Table S1)

100 for the most reactive chars, sewage sludge and RDF. These indicate that the kinetics play a dominant role;

101 hence, mass transport limitations were neglected in the estimation of kinetic parameters.

$102 \quad 2.4$ Physiochemical fuel and char properties

103 The specific BET surface area and the mesoporosity $(\mathrm{BJH})$ of the chars were determined from $\mathrm{N}_{2}$ 104 adsorption at its boiling point $(77 \mathrm{~K})$ in the $\mathrm{p} / \mathrm{p}_{0}$ range of $0.01-0.99$. The carbon, hydrogen, nitrogen, and 105 sulphur content, and inorganic element concentration of the raw fuels and chars were determined by 106 standard CHNS and inductively coupled plasma emission spectroscopy (ICP-OES), respectively.

107 Table 1 displays selected properties of the raw fuels. The complete ICP-OES results for the raw fuels 108 and chars can be found in the supplemental material (Table S2). 


\begin{tabular}{|l|c|c|c|c|c|c|c|c|c|c|c|}
\hline & \multicolumn{5}{|c|}{ [wt\% d.b.] } & \multicolumn{5}{c|}{ [mg/kg d.b.] } \\
\hline Fuel & C & H & N & S & Ash & K & P & Mg & Ca & Fe & Na \\
\hline S & 46.9 & 6.0 & 0.56 & 0.12 & 4.2 & 14000 & 910 & 960 & 2300 & 41 & 230 \\
\hline SSL & 29.0 & 3.8 & 3.80 & 0.96 & 50.2 & 6300 & 34000 & 4300 & 37000 & 85000 & 2400 \\
\hline RDF & 48.7 & 6.6 & 1.16 & 0.28 & 16.4 & 1600 & 760 & 4440 & 37300 & 454 & 2000 \\
\hline
\end{tabular}

Table 2 summarizes the ultimate analysis, char yield, and selected ash composition of the chars. The

112 char yields of the demineralized fuels were lower than those of the raw fuels, as expected. Due to the large

113 ash content, the waste chars contained a significantly lower carbon content in comparison with that of the

114 biomass chars. Demineralization halved the ash content of the straw char, while only a small decrease was

115 observed for sewage sludge char. Demineralization of sewage sludge removed a significant amount of

116 calcium and to a lesser extent potassium and iron. Although dependent on the chemical association,

117 previous studies have elucidated the catalytic importance of these elements and additionally that of sodium

118 and magnesium in the NO-char reaction [16]. In this study, the major catalytic elements are expected to 119 be potassium, calcium and iron.

Table 2: Elemental and proximate analysis of the chars

\begin{tabular}{|l|c|c|c|c|c|c|c|c|c|c|c|c|}
\hline & \multicolumn{9}{|c|}{ [wt\% d.b.] } & \multicolumn{5}{c|}{ [mg/kg d.b.] } \\
\hline Char & C & H & N & S & Ash & $\begin{array}{c}\text { Char } \\
\text { Yield }\end{array}$ & K & P & Mg & Ca & Fe & Na \\
\hline S & 72.38 & 1.42 & 0.45 & 0.029 & 18.7 & 25.8 & 43642 & 2789 & 2329 & 4459 & $<3$ & 740 \\
\hline SSL & 17.91 & 0.52 & 1.37 & 0.188 & 79.4 & 56.7 & 5803 & 16708 & 6745 & 61579 & 39697 & 1485 \\
\hline RDF & 39.91 & 1.21 & 1.21 & 0.728 & 56.7 & 31.2 & 4314 & 1673 & 9778 & 95688 & 9675 & 5880 \\
\hline $\begin{array}{l}\text { DM } \\
\text { S }\end{array}$ & 82.15 & 1.53 & 0.83 & 0.032 & 8.4 & 16.9 & 530 & 727 & $<0.2$ & 283 & $<3$ & $<120$ \\
\hline
\end{tabular}




\begin{tabular}{|l|l|l|l|l|l|l|l|l|l|l|l|l|}
\hline $\begin{array}{l}\text { DM } \\
\text { SSL }\end{array}$ & 22.28 & 0.56 & 1.99 & 0.107 & 76.8 & 56.5 & 3090 & 10614 & 4175 & 5698 & 33059 & 603 \\
\hline
\end{tabular}

122 Table 3 shows the BET surface area, pore volume, and mean pore diameter of the chars. The 123 demineralized and raw sewage sludge char surface areas were similar, while the RDF and straw chars 124 displayed lower values. In comparison, demineralized straw char exhibited a high surface area and 125 consequently pore volume; however, the volume and surface area mainly stem from micro- and some 126 mesopores, leading to small pore diameters. Although some disagreement exists, it is widely accepted 127 that surface area and pore structure play an important role in the NO reduction reaction [11]. While it has 128 been difficult to correlate the NO-char reaction rate with BET areas, incorporating the surface area 129 associated with macro- and some mesopores (<20nm by mercury porosimetry) yielded a better basis [6]. 130 Table 3: BET surface area (SA), pore volume $\left(\mathrm{V}_{\mathrm{p}}\right)$, and mean pore diameter $\left(\mathrm{d}_{\mathrm{p}, \mathrm{mean}}\right)$ of the chars. Note, 131 demineralized straw char contained both micro- and mesopores.

\begin{tabular}{|l|c|c|c|}
\hline Char & $\mathbf{S A ~}\left[\mathbf{m}^{2} / \mathbf{g}\right]$ & $\mathbf{V} \mathbf{P}\left[\mathbf{c m}^{\mathbf{3}} / \mathbf{g}\right]$ & $\mathbf{d}_{\mathbf{p}, \text { mean }}[\mathbf{n m}]$ \\
\hline $\mathrm{S}$ & 25.1 & $2.4 \cdot 10^{-2}$ & 3.404 \\
\hline SSL & 66.0 & $9.0 \cdot 10^{-2}$ & 4.856 \\
\hline RDF & 43.2 & $7.1 \cdot 10^{-2}$ & 3.385 \\
\hline DM S & 429.5 & 0.18 & $1.932 / 3.382$ \\
\hline DM SSL & 55.8 & $7.2 \cdot 10^{-2}$ & 4.852 \\
\hline
\end{tabular}

\section{Kinetics of NO reduction}

134 The reactivity of solid fuel chars towards NO is commonly evaluated from globalized first order rate 135 expressions [17-20], where the reaction rate is frequently based on the mass of carbon in the char. 136 Globalized rates are useful in Computational Fluid Dynamic (CFD) simulations [21], since more detailed 137 schemes require extensive computational requirements. The kinetic data for the NO-char reaction can be 
138 obtained from fixed bed reactor experiments under the assumption of plug flow in quasi steady state. The 139 integral form of the design equation is shown in Eq. 1 for a first order rate expression.

$$
-\ln \left(1-\mathrm{X}_{\mathrm{NO}}\right)=\mathrm{k}_{\mathrm{NO}} \cdot \mathrm{W} / \mathrm{V}_{\mathrm{g}}
$$

Eq. 1

141 Here, $\mathrm{X}_{\mathrm{NO}}(-)$ is the conversion of $\mathrm{NO}, \mathrm{k}_{\mathrm{NO}}\left(\mathrm{m}^{3}\right.$ gas $\left.\mathrm{s}^{-1} \mathrm{~kg}_{-} \mathrm{C}^{-1}\right)$ is the carbon mass based first order rate 142 constant, $\mathrm{W}(\mathrm{kg}-\mathrm{C})$ is the instantaneous carbon mass in the bed, and $\mathrm{V}_{\mathrm{g}}\left(\mathrm{m}^{3}\right.$ gas $\left./ \mathrm{s}\right)$ is the volumetric gas 143 flowrate. The instantaneous carbon mass was determined from the $\mathrm{CO}$ and $\mathrm{CO}_{2}$ measurements during $\mathrm{NO}$ 144 reduction experiments.

145 The conversion of char nitrogen to NO in fixed bed char combustion was investigated using a one146 dimensional, transient, heterogeneous reactor model followed by a one-parameter description of the flue 147 gas mixing in the downstream process using $n$ stirred tank reactors in series. The residence time 148 distribution methodology and results are demonstrated in the supplemental material (Figure S1 and Table 149 S3). The main nitrogen products of char nitrogen oxidation are $\mathrm{NO}, \mathrm{N}_{2}, \mathrm{HCN}$, and $\mathrm{N}_{2} \mathrm{O}$ [6]. Based on 150 FTIR measurements, the nitrogen combustion products by direct char oxidation were assumed to be NO 151 with a fraction $\mathrm{f}_{\mathrm{NO}}$ and $\mathrm{N}_{2} \mathrm{O}$ with a fraction $\mathrm{f}_{\mathrm{N}_{2} \mathrm{O}}$, while $\mathrm{N}_{2}$ was formed by the reduction of NO over char. 152 The reduction of $\mathrm{N}_{2} \mathrm{O}$ to $\mathrm{N}_{2}$ over char was not examined in this work. The conservation equation for the 153 gas and solid phase in the packed bed reactor are shown in Eq. 2 and 3, respectively [22], along with the 154 initial and boundary conditions.

$$
\begin{gathered}
\frac{\mathrm{dC}_{\mathrm{char}}}{\mathrm{dt}}=-\epsilon \mathrm{R}_{\mathrm{C}} \\
\frac{\delta \mathrm{C}_{\mathrm{i}}}{\delta \mathrm{t}}=\mathrm{D}_{\mathrm{ax}} \frac{\delta \mathrm{C}_{\mathrm{i}}^{2}}{\delta \mathrm{x}^{2}}-\mathrm{u}_{\mathrm{int}} \frac{\delta \mathrm{C}_{\mathrm{i}}}{\delta \mathrm{x}}-\mathrm{R}_{\mathrm{C}} \\
\mathrm{C}(\mathrm{t}=0)=\mathrm{C}_{0} \text { where } \mathrm{C}_{0}=\left[\begin{array}{l}
\mathrm{C}_{\mathrm{O}_{2}, 0}=1.11 \frac{\mathrm{mol}}{\mathrm{m}_{\text {gas }}^{3}} \\
\mathrm{C}_{\mathrm{CO}_{2}, 0}=0 \frac{\mathrm{mol}}{\mathrm{m}_{\text {gas }}^{3}} \\
\mathrm{C}_{\mathrm{CO}, 0}=0 \frac{\mathrm{mol}}{\mathrm{m}_{\text {gas }}^{3}} \\
\mathrm{C}_{\mathrm{NO}, 0}=0 \frac{\text { mol }}{\mathrm{m}_{\text {gas }}^{3}}
\end{array}\right] \\
\mathrm{C}(\mathrm{x}=0)=\mathrm{C}_{0}
\end{gathered}
$$




$$
\mathrm{dC}\left(\mathrm{x}=\mathrm{h}_{\text {react }}\right)=0
$$

160 Here, $\mathrm{C}_{\text {char }}\left(\mathrm{mol} / \mathrm{m}^{3}\right.$ reactor) is the molar concentration of carbon in the reactor, $\mathrm{C}_{\mathrm{i}}\left(\mathrm{mol} / \mathrm{m}^{3}\right.$ gas) is the 161 concentration of gas component $\mathrm{i}\left(\mathrm{i}=\mathrm{CO}, \mathrm{CO}_{2}, \mathrm{O}_{2}, \mathrm{NO}\right), \mathrm{t}(\mathrm{s})$ is the time, $\mathrm{x}(\mathrm{m})$ is the coordinate along the 162 bed, $\epsilon(-)$ is the bed porosity, $D_{a x}\left(\mathrm{~m}^{2} / \mathrm{s}\right)$ is the axial dispersion coefficient, determined from the Gunn 163 correlation [23], $\mathrm{u}_{\text {int }}(\mathrm{m} / \mathrm{s})$ is the interstitial gas velocity, and $\mathrm{R}_{\mathrm{C}}\left(\mathrm{mol} / \mathrm{m}^{3}\right.$ gas $\left./ \mathrm{s}\right)$ is the char oxidation rate.

164 The energy conservation equation and initial conditions for the solid phase is shown in Eq. 4. As the 165 char constitutes $1 \%$ of the bed material, the energy equation was based on the silica sand. Hence, it is 166 assumed that the temperature of the char equals that of the sand at any given time. Moreover, due to the 167 heating elements around the reactor, the temperature of the gas phase was assumed to be constant. This 168 assumption was validated by the thermocouple below the bed, showing a discrepancy of $\pm 7^{\circ} \mathrm{C}$. The energy 169 equation includes effects from conductivity, convection, and char combustion. Radiation was neglected 170 as the influence of this on the overall heat transfer was estimated to be around $10 \%$.

$$
\mathrm{C}_{\text {sand }} \mathrm{C}_{\mathrm{p} \text {,sand }} \frac{\delta \mathrm{T}_{\text {sand }}}{\delta \mathrm{t}}=\mathrm{k}_{\mathrm{eff}} \frac{\delta \mathrm{T}_{\text {sand }}^{2}}{\delta \mathrm{x}^{2}}+\mathrm{h} \mathrm{S}\left(\mathrm{T}_{\text {gas }}-\mathrm{T}_{\text {sand }}\right)+\epsilon \Delta \mathrm{H}_{\mathrm{R}} \mathrm{R}_{\mathrm{C}}
$$

$$
\mathrm{T}_{\text {sand }}(\mathrm{t}=0)=\mathrm{T}_{0} \text { where } \mathrm{T}_{0}=298 \mathrm{~K}
$$$$
\mathrm{T}_{\text {sand }}(\mathrm{x}=0)=\mathrm{T}_{\mathrm{f} 0} \text { where } \mathrm{T}_{\mathrm{f} 0}=1073 \mathrm{~K}
$$

$$
\operatorname{dT}_{\text {sand }}\left(\mathrm{x}=\mathrm{h}_{\text {react }}\right)=0
$$

Here, $\mathrm{C}_{\text {sand }}\left(\mathrm{mol} / \mathrm{m}^{3}\right.$ reactor $)$ is the molar concentration of sand in the reactor, $\mathrm{C}_{\mathrm{p}}(\mathrm{kJ} / \mathrm{mol} / \mathrm{K})$ is the specific heat capacity of sand, $T_{\text {sand }}(K)$ is the sand temperature, $k_{\text {eff }}(\mathrm{kJ} / \mathrm{m} / \mathrm{s} / \mathrm{K})$ is the effective thermal conductivity determined from [24], $\mathrm{h}\left(\mathrm{kJ} / \mathrm{m}^{2} / \mathrm{s} / \mathrm{K}\right)$ is the gas-solid heat transfer coefficient, $\mathrm{S}\left(\mathrm{m}^{2} / \mathrm{m}^{3}\right)$ is the volumetric solid surface area, and $\Delta \mathrm{H}_{\mathrm{R}}$ is the enthalpy of reaction between $\mathrm{O}_{2}$ and char to form CO ($110.5 \mathrm{~kJ} / \mathrm{mol})$ and $\mathrm{CO}_{2}(-396.6 \mathrm{~kJ} / \mathrm{mol})$. The fraction of $\mathrm{CO}_{2}$ formed from char combustion was determined from the experimentally obtained concentration profiles. For straw, sewage sludge, and RDF 181 chars, this parameter was set at $0.99,0.95$, and 0.97 , respectively.

182 The char combustion rate was simplified to an expression first order in oxygen and char concentration, 183 Eq. 5. The formation of NO was assumed proportional to the char combustion rate, Eq. 6, while the 
184 reduction was determined from the experimentally obtained rate constant, Eq. 7. The net formation of NO 185 was thereby calculated by the difference in formation and reduction, Eq. 8.

$$
\mathrm{R}_{\mathrm{C}}=\mathrm{k} \cdot \mathrm{C}_{\mathrm{Char}} \cdot \mathrm{C}_{\mathrm{O}_{2}} \text {, where } \mathrm{k}=\mathrm{A}_{\mathrm{C}} \cdot \exp \left(-\mathrm{E}_{\mathrm{a}, \mathrm{C}} / \mathrm{R} / \mathrm{T}\right)[=] \frac{\mathrm{m}_{\text {reactor }}^{3}}{\mathrm{~mol} \mathrm{~s}}
$$

To describe the dispersion downstream to the reactor, $n$ stirred tank reactors in series were assumed.

191 The number of reactors in series was determined from residence time distribution measurements. For each tank, the mass conservation equation assuming no reaction is shown in Eq. 9.

$$
\frac{\mathrm{dC}_{\mathrm{i}}}{\mathrm{dt}}=\frac{1}{\tau}\left(\mathrm{C}_{\mathrm{i}, \text { in }}-\mathrm{C}_{\mathrm{i}, \text { out }}\right)
$$

Here, $\tau$ denotes the residence time in one tank. The coupled differential equations were solved by was used to describe the reduction of NO over char.
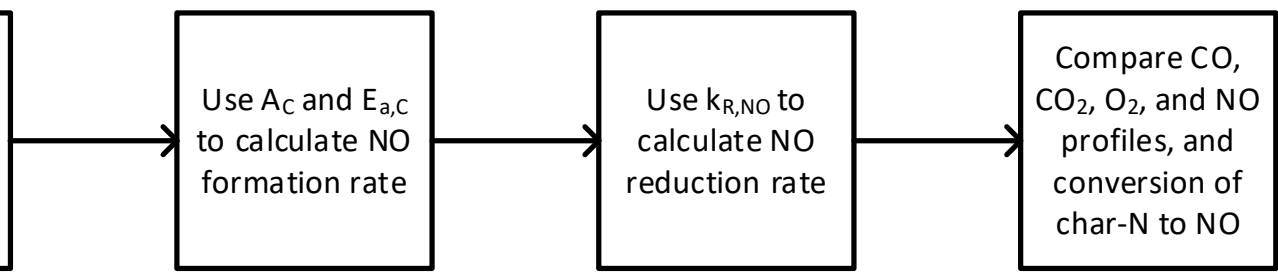

Figure 3: Schematic representation of the combustion model. 
204 Since the optimization problem is non-convex, the MLE function depends on the starting values of the 205 parameters to be optimized. The initial guess of the parameters were based on the previous study of 206 Karlström et al. [26]. In the case of sewage sludge char combustion, a strong correlation was noted 207 between the two kinetic parameters. This resulted in a large standard deviation, causing the lower limit of 208 the pre-exponential factor to be negative, i.e. non-unique estimate of this parameters. Consequently, the 209 activation energy was specified as a parameter and only the pre-exponential factor was fit to the data. To 210 get a unique estimate of the activation energy and pre-exponential factor, additional experiments must be 211 planned, e.g. combustion at different temperatures. An example of concentration plots from combustion 212 modelling is illustrated in the supplemental material (Figure S2).

$$
\mathrm{A}_{\text {initial }}=100 \frac{\mathrm{m}_{\mathrm{react}}^{3}}{\mathrm{~mol} \mathrm{~s}} \quad \mathrm{E}_{\mathrm{a}, \text { initial }}=50-60 \mathrm{~kJ} / \mathrm{mol}
$$




\section{Results and Discussion}

\section{$215 \quad$ 4.1 Reduction of NO over char}

216 Figure 4a illustrates the conversion of $400 \mathrm{ppmv}$ NO over $50 \mathrm{mg}$ char at $800^{\circ} \mathrm{C}$, while Figure $4 \mathrm{~b}$ depicts 217 the corresponding transient first order rate constant of the chars. The results in Figure 4a demonstrate that 218 an almost complete reduction of NO was achieved for the raw sewage sludge and RDF chars, while the 219 straw char showed a somewhat lower reduction of NO. The NO reduction was lower for the demineralized 220 fuel chars as compared to the raw fuel chars. The results of Figure $4 \mathrm{~b}$ indicate that the reactivities of the 221 waste chars were significantly higher than those of the straw char. The NO reduction rate of the sewage 222 sludge char was approximately 12 times that of the straw char, while the RDF char exhibited half the 223 reactivity of the sewage sludge char and six times that of the straw char. From Table 2, it is observed that 224 the straw char contained the highest amount of potassium, which is likely to be the most active element 225 in catalyzing NO reduction [8]. In comparison, the waste based chars exhibited a larger content of iron, 226 calcium, and sodium, all of which may catalyze the NO reduction and thereby compensate for the lower 227 potassium content compared to straw char. In addition, although the conversion of NO of the 228 demineralized sewage sludge char was lower than that of straw char in Figure 4a, it is suggested based on 229 Figure $4 \mathrm{~b}$ that the carbon in the former is more reactive than the latter, probably due to the larger content 230 of iron. The demineralized straw char, showing the highest surface area and pore volume among the chars, 231 displayed the lowest reactivity, as very small amounts of catalytic elements were present in the structure. 232 Moreover, this char exhibited the lowest average pore diameter, which could be an additional contributing 233 factor for the low reactivity. In several chars, a transient kinetic behavior followed by a steady state 234 reduction rate was observed, similar to the observations of Garijo et al. [27,28] and Zhao et al. [29]. This 235 behavior is further discussed in the following sections. The repeatability of the experimental results was 236 examined, showing a relative standard error of maximum 4\%, as seen in the supplemental material (Figure 237 S3). 
(a)

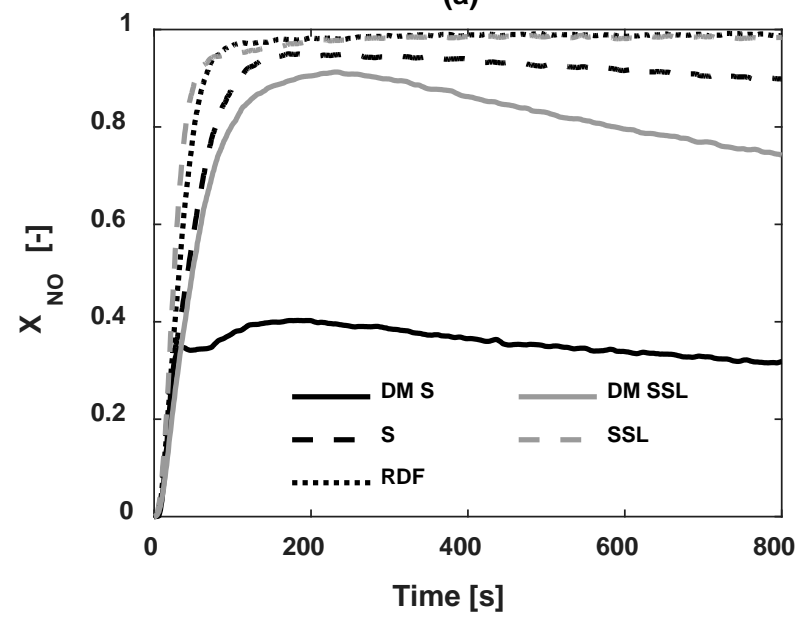

(b)

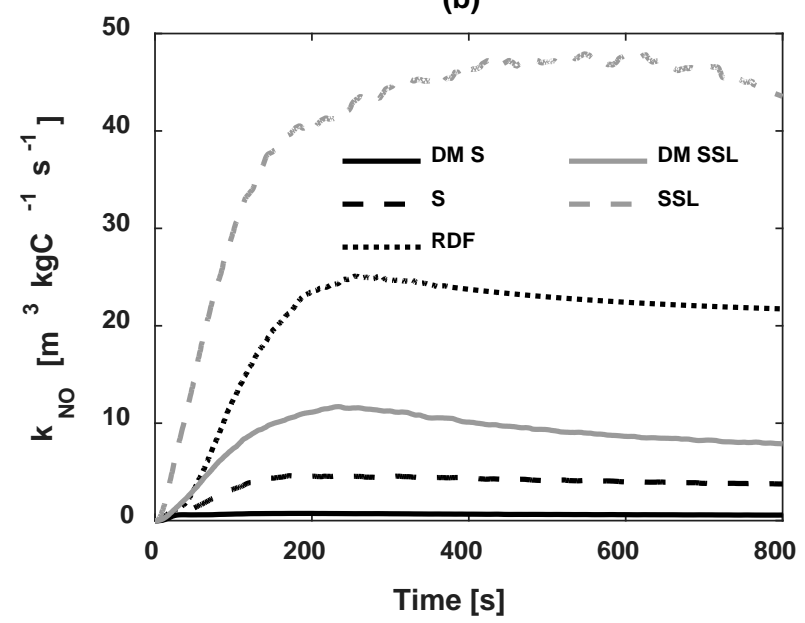

239 Figure 4: Conversion of $\mathrm{NO}\left(\mathrm{X}_{\mathrm{NO}}\right)$ (50 mg char) (a) and first order carbon mass based reaction rate 240 constant $\left(\mathrm{k}_{\mathrm{NO}}\right)$ for the NO reduction (b) versus reaction time for the five different chars at $800^{\circ} \mathrm{C}$ using an 241 inlet NO concentration of 400 ppmv NO.

\section{$\underline{4.2 \text { Effect of ash forming elements on reactivity }}$}

243 Figure 5 presents the maximum rate constant at $800^{\circ} \mathrm{C}$ and $400 \mathrm{ppmv} \mathrm{NO}$ as a function of the molar ratio of $(\mathrm{Fe}+\mathrm{Ca}+\mathrm{K}) / \mathrm{C}(\mathrm{a})$ and the BET surface area (b) in the unreacted chars. Iron, calcium, and potassium may influence the catalytic activity through different pathways. However, for simplicity, the catalytic term was defined as the molar ratio $(\mathrm{Fe}+\mathrm{Ca}+\mathrm{K}) / \mathrm{C}$. The maximum rate constant was chosen to describe the initial reactivity, since the preliminary increase in reactivity was attributed to particle heating and NO accumulation, and therefore negligible deactivation was assumed prior to this point. The initial rate the initial reactivity is proportional to the molar ratio of $(\mathrm{Fe}+\mathrm{Ca}+\mathrm{K}) / \mathrm{C}$ in the unreacted chars. A higher

251 content of calcium, iron, and potassium would conceivably enhance R7 and R8, thereby facilitating the 252 NO reduction. Given the variable chemical and physical properties of the waste based fuels, this 253 observation provides a method of classifying the fuel chars in terms of their reactivity towards NO. 254 Although the mass ratio could be used as a basis to describe the reactivity prior to deactivation of the 255 chars, the long-term reactivity cannot purely be based on this due to the complicated transient char 
structure change and ash transformation. Moreover, there appears to be no direct correlation between the

257 surface area and reactivity even when neglecting DM straw, presumably due to the significant effect of 258 ash forming elements and narrow surface area sample size [11].
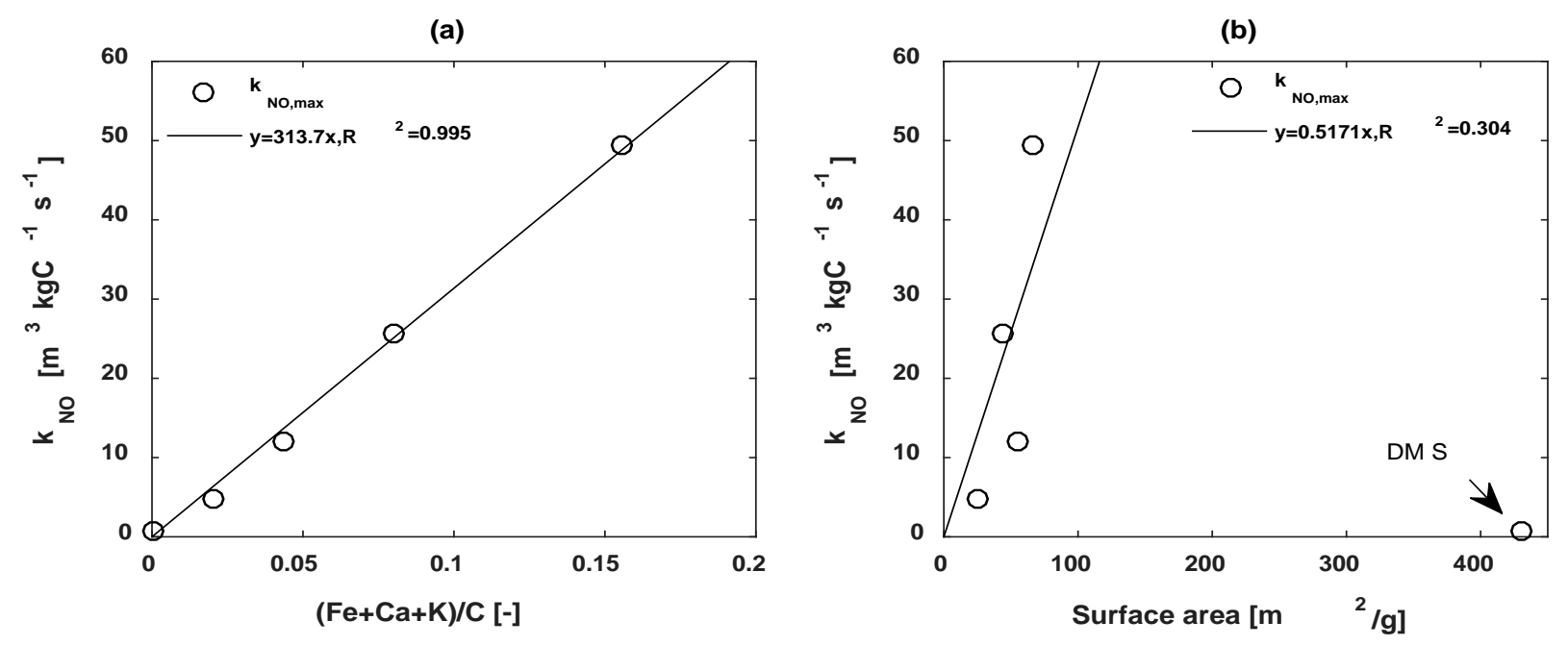

260 Figure 5: Maximum first order reaction rate constant $\left(\mathrm{k}_{\mathrm{NO}, \max }\right)$ of the examined chars against the initial 261 concentration of iron, calcium, and potassium expressed in mol element per mol carbon (a) and the BET 262 surface area. (b) The rate constant was determined from reduction experimentation at $800^{\circ} \mathrm{C}$ and 400 263 ppmv NO.

$\underline{4.3 \text { Influence of temperature and NO inlet concentration }}$

265 Figure 6 depicts $\mathrm{k}_{\mathrm{NO} \text {,max }}$ against 1/T at varying NO inlet concentrations for sewage sludge and RDF 266 chars. In agreement with previous studies, the reactivity increased with temperature [30]. The results show 267 that the rate constant depends on the NO inlet concentration, thereby indicating a fractional dependence 268 on the NO concentration. However, a reliable estimate of the reaction order and rate constant could not 269 be made using a global fractional order rate expression, as the reaction order was strongly dependent on 270 the temperature and carbon conversion. More complex models are necessary to fully describe the char 271 reactivity, as discussed further in the following sections. However, for simplicity and as a first attempt to 272 provide a rate expression for NO reaction with sewage sludge/RDF char in large-scale simulations, e.g. in 273 CFD modelling [21], concentration averaged rate constants were derived using the results shown in Figure 
274 6. For the averaged $\mathrm{k}_{\mathrm{NO} \text {,max }}$, the recommended kinetic parameters to be used for modelling purposes are 275 summarized in Table 4.

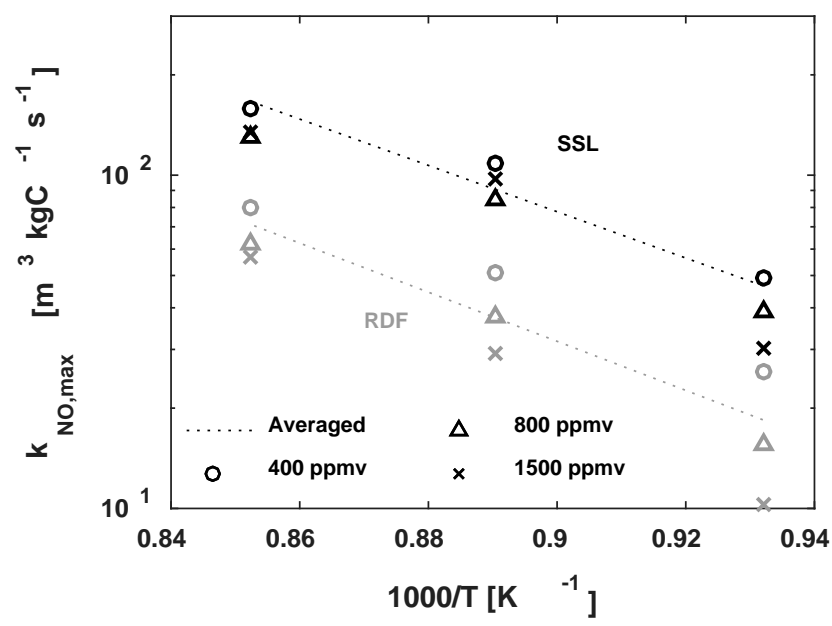

277 Figure 6: Arrhenius plot of the maximum carbon mass based reaction rate constant ( $\left.\mathrm{k}_{\mathrm{NO} \text {,max }}\right)$ for NO 278 reduction over RDF and sewage sludge chars at varying NO inlet concentrations. The symbols in black 279 and grey refer to sewage sludge and RDF chars, respectively, while the dotted lines represent the averaged 280 rate constants.

281 Table 4: Pre-exponential factor $\mathrm{A}\left(\mathrm{m}^{3} \mathrm{kgC}^{-1} \mathrm{~s}^{-1}\right)$ and activation energy $\mathrm{E}_{\mathrm{a}}(\mathrm{kJ} / \mathrm{mol})$ for reduction of NO 282 over char.

\begin{tabular}{|c|c|c|}
\hline Char & A & $\mathbf{E a}$ \\
\hline Straw & $3.91 \cdot 10^{7}$ & 145 \\
\hline Sewage sludge & $1.39 \cdot 10^{8}$ & 133 \\
\hline Refuse derived fuel & $1.35 \cdot 10^{8}$ & 141 \\
\hline
\end{tabular}

\section{$\underline{4.4 \text { Formation and reduction of NO in char combustion }}$}

285 The form of the char nitrogen combustion product distribution, determined by FTIR, is illustrated in 286 Figure 7. As it was not possible to measure $\mathrm{N}_{2}$ and $\mathrm{HCN}$, these were calculated as a rest fraction based on 287 the material balance. The presence of HCN during char combustion has previously been reported [31,32]. 
288 However, unless radical quenching compounds such as iodine are added, the amount is often small in a 289 combustion atmosphere [33]. Consequently, the rest fraction was presumed to consist mainly of $\mathrm{N}_{2}$. The 290 results show that the majority of the emitted nitrogen was in the form of $\mathrm{NO}$ and $\mathrm{N}_{2}$ with a smaller quantity 291 of $\mathrm{N}_{2} \mathrm{O}$. In addition, no significant amounts of $\mathrm{NH}_{3}, \mathrm{HNCO}$, and $\mathrm{NO}_{2}$ were detected. It has previously 292 been suggested that the fractional conversion of char nitrogen to $\mathrm{N}_{2} \mathrm{O}$ increased with the char nitrogen 293 content or the NO concentration [34]. In agreement with this, the straw, RDF, and sewage sludge chars 294 exhibited a fractional conversion to $\mathrm{N}_{2} \mathrm{O}$ of $1 \%$, $2 \%$, and $7 \%$, respectively. The formation mechanisms of $295 \mathrm{~N}_{2} \mathrm{O}$ during char combustion were suggested to be by direct char nitrogen oxidation (R1 and R10), 296 reaction between char nitrogen and NO (R11, reverse R2 and R10, or direct reaction between NO and (297 CN) [35]), or release and subsequent homogeneous oxidation of HCN. In general, the reaction between ($298 \mathrm{CN}$ ) and NO can be disregarded [6], since no $\mathrm{N}_{2} \mathrm{O}$ was detected without the presence of oxygen [36-38]. 299 This was additionally verified in this study, where the products of NO reduction over char were 300 investigated using FTIR, showing that no significant amounts of $\mathrm{N}_{2} \mathrm{O}, \mathrm{HNCO}, \mathrm{NH}_{3}$, and $\mathrm{NO}_{2}$ were 301 formed. The relative importance of the homogeneous and heterogeneous mechanisms of $\mathrm{N}_{2} \mathrm{O}$ formation 302 is as of yet unknown [32]. In the combustion model, $\mathrm{N}_{2} \mathrm{O}$ was presumed to form primarily by direct 303 oxidation of char nitrogen, with a fractional conversion $f_{\mathrm{N}_{2} \mathrm{O}}$ equal to that measured by FTIR. This would 304 lead to an overestimation of the actual $\mathrm{NO}$ fractional conversion $\mathrm{f}_{\mathrm{NO}}$, as $\mathrm{N}_{2} \mathrm{O}$ is believed to decompose 305 over the char at an even faster rate than NO reduction [39].

$$
\begin{array}{llll}
(-\mathrm{CN})+(-\mathrm{CNO}) & \rightarrow & \mathrm{N}_{2} \mathrm{O}+2(-\mathrm{C}) & \mathrm{R} 10 \\
\mathrm{NO}+(-\mathrm{CNO}) & \rightarrow & \mathrm{N}_{2} \mathrm{O}+(-\mathrm{CO}) & \mathrm{R} 11
\end{array}
$$




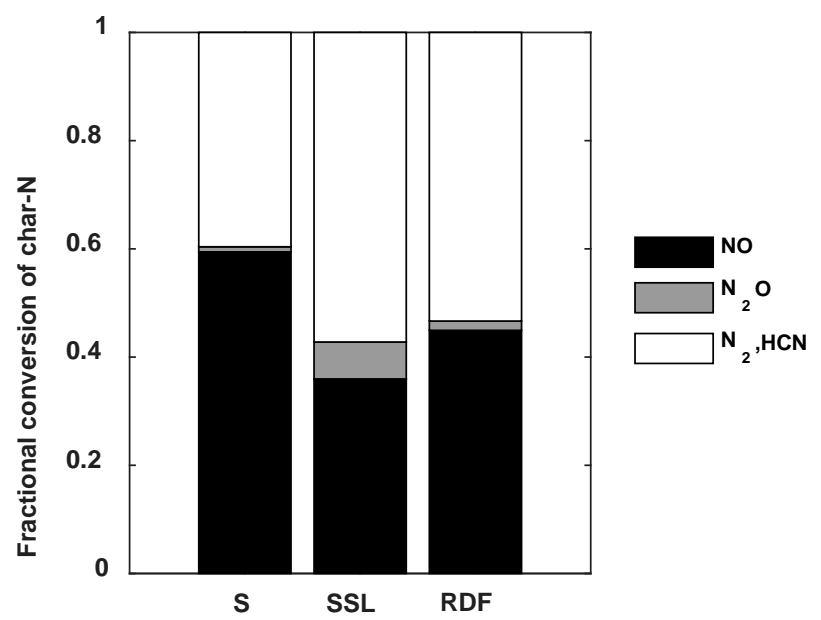

308 Figure 7: Nitrogen product distribution from char combustion at $800^{\circ} \mathrm{C}$ in $10 \% \mathrm{O}_{2} . \mathrm{NH}_{3}, \mathrm{HNCO}$, and $\mathrm{NO}_{2}$ were not detected in significant quantities and therefore not shown here.

310 Figure 8 presents the experimental and modelled NO combustion selectivity (a) and concentration 311 profiles (b) from fixed bed char combustion at $800^{\circ} \mathrm{C}$ in $10 \mathrm{vol} \% \mathrm{O}_{2}$. Although the nitrogen content in the 312 RDF and sewage sludge chars were higher than in straw char, the experimental selectivity to form NO 313 was lower. The concentration averaged $\mathrm{k}_{\mathrm{NO} \text {,max }}$ were used in the computations since the time for complete 314 combustion of the chars was short, i.e., 20-30 s. A reasonable prediction of the conversion of char nitrogen 315 to NO was achieved for the straw and RDF chars, while the conversion of sewage sludge char nitrogen to 316 NO was slightly overestimated. This was additionally reflected in the concentration plots, wherein the 317 qualitative trend of the data was well described with minor quantitative differences. In the case of sewage 318 sludge and RDF, a slight overestimation of the NO release near the maximum was observed. As the 319 formation of by-products were not the cause between model and experiment, the discrepancies were 320 apparently a consequence of NO reduction by CO over char and ash (R4) [40] or reactivity enhancement 321 by the presence of $\mathrm{O}_{2}$ [29]. In addition to this, the experimental release of NO in RDF char was higher 322 than predicted at later stages in the combustion. This could be caused by the assumption that the NO 323 formation is proportional to the carbon burnout. Although, this is a common simplification in several char324 NO modelling studies [30,41,42], the proportionality between the rates for coal chars is not always 
325 prominent [6], especially at temperatures around $600^{\circ} \mathrm{C}$ [32]. For the purposes of this study, the simplified 326 combustion model provided reasonable predictions of the NO concentration profile and the conversion of 327 char nitrogen to NO during combustion of straw and RDF chars. For the sewage sludge chars, the 328 reduction rate constant was two times lower in an inert atmosphere, as compared to the combustion 329 atmosphere. The results here indicate that the averaged rate constants could be useful in predicting the 330 reactivity of the raw chars towards $\mathrm{NO}$, and therefore potentially be implemented in large-scale 331 simulations. However, it should be taken into consideration that the results provided here are based on a 332 limited range of operating conditions as well as on several assumptions, which would require further 333 evaluation. Some of these are discussed in the following section.

(a)

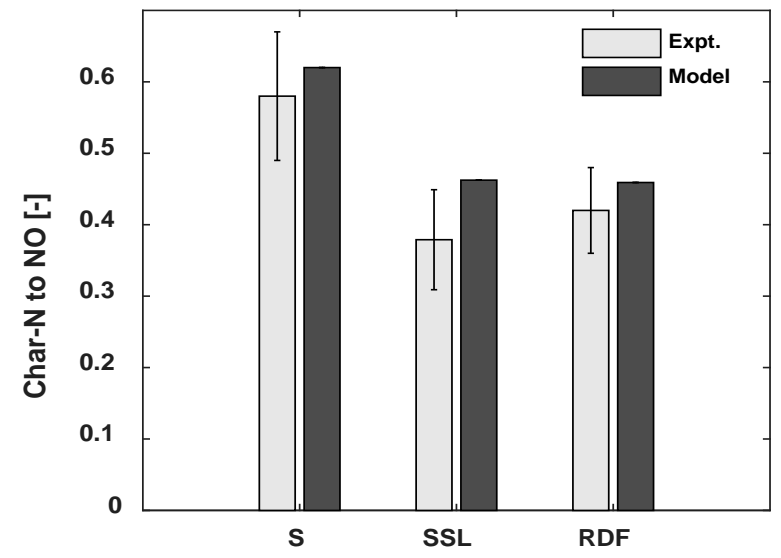

334

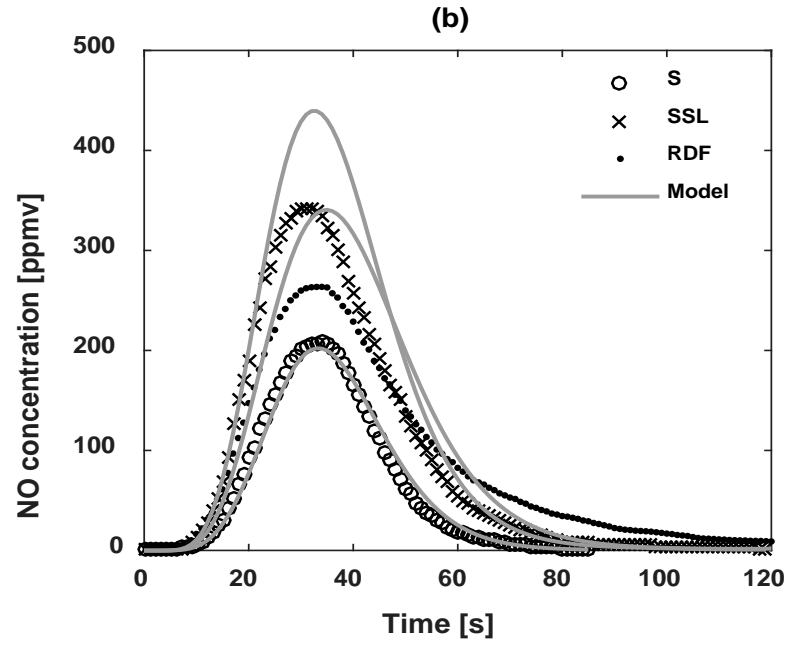

Figure 8: Experimental and predicted NO selectivity (a) and concentration profiles (b) from the combustion raw chars at $800^{\circ} \mathrm{C}$ in $10 \mathrm{vol} \% \mathrm{O}_{2}$. The error bars depict the repeatability of the experiments. The predictions were made using a concentration averaged first order reaction rate in the combustion model presented in Eq. 2-9.

\section{$\underline{4.5}$ Assessment of the rate expression}

Figure 9 illustrates the first order rate constant against the reaction time (a) and carbon conversion (b) for sewage sludge, RDF, and straw chars. Unless otherwise stated in the legend, the data are extracted from the $900^{\circ} \mathrm{C}$ and 1500 ppmv NO experiments. In Figure 9a, all chars exhibited a maximum reactivity 
343 followed by a steady decline, the slope of which differed depending on temperature and NO inlet

344 concentration. It became obvious that the reactivity decrease was not caused by carbon depletion, as

345 illustrated in Figure 9b. Possible explanations for the declining reactivity are deactivation due to a long 346 char residence time, formation of thermally stable oxides, and change in carbon active sites [6,27]. As

347 thermal annealing is expectedly of smaller importance at the investigated temperatures, the dominating

348 deactivation mechanism from long char residence times may be caused by transformation of catalytic ash

349 species, e.g. evaporation of potassium or formation of possibly less-catalytic silicates of calcium and iron.

350 Additionally, the production of surface complexes could lead to a blockage of the pores or active sites,

351 thereby inhibiting reactions R8 and R9, wherein the catalytic site is regenerated and a new carbon site is

352 formed. Further, the internal surface area may increase or decrease during carbon conversion, thus

353 influencing the availability and number of active sites for NO reduction. To capture the effects of NO

354 concentration and carbon conversion, fractional order and Random Pore Model (RPM) [43] rate

355 expressions were employed; however, none of these yielded obvious advantages in comparison with the

356 simple first order equation, as seen in the supplemental material (Figure S4). In future work, a more

357 thorough understanding of the deactivation mechanism, i.e. change in surface structure and ash forming

358 element content, as a function of time and carbon conversion is needed to describe the reduction reactivity

359 of waste chars.
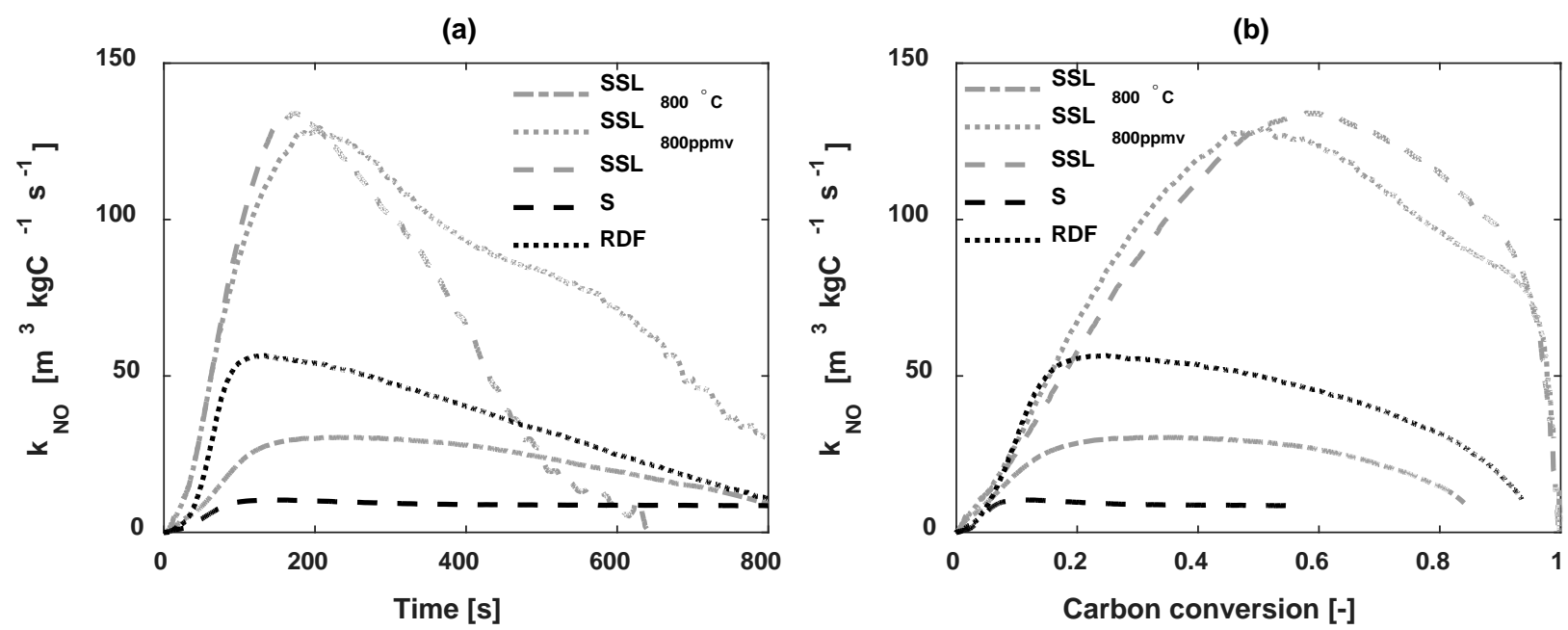
361 Figure 9: First order carbon mass based rate constant ( $\mathrm{k}_{\mathrm{NO}}$ ) versus time on stream (a) and carbon conversion (b) at $900^{\circ} \mathrm{C}$ and 1500 ppmv NO. Additional data for sewage sludge from $900^{\circ} \mathrm{C}$ and 800 ppmv NO, and $800^{\circ} \mathrm{C}$ and 1500 ppmv NO.

\section{$\underline{4.6 \text { Comparison of reactivity with literature data }}$}

365 Figure 10 compares the obtained reaction rates with selected literature values. The results indicate that 366 the waste chars in general exhibited a higher reactivity than biomass chars and significantly higher than 367 the rate constant recommended by Levy et al. [17] for coal char, the default choice for char $+\mathrm{NO}$ in 368 ANSYS Fluent 18.0. Although the chars employed in this study were to some extent deactivated by the 369 pyrolysis in the horizontal oven, the obtained rate of sewage sludge char was higher than and the RDF 370 char comparable to that of bark and straw char reported by Zhao et al. [29], wherein the pyrolysis time 371 was minimized and oxygen was introduced to enhance the kinetics. Similarly, the reactivity of the waste 372 chars exceeded the rates reported by Garijo et al. [27], who performed in-situ pyrolysis to minimize the 373 thermal deactivation.

374 The results of the present study provide an indication of the potential utilization of waste char in the 375 reduction of NO in thermal conversion processes. This could possibly be by primary measures if the fuel 376 and air feeding is controlled in such a way that the more reactive chars are present at reducing conditions 377 within the boiler or through secondary techniques, if the char is employed subsequent to the combustion chamber, e.g. char bed or direct injection to the cyclone.

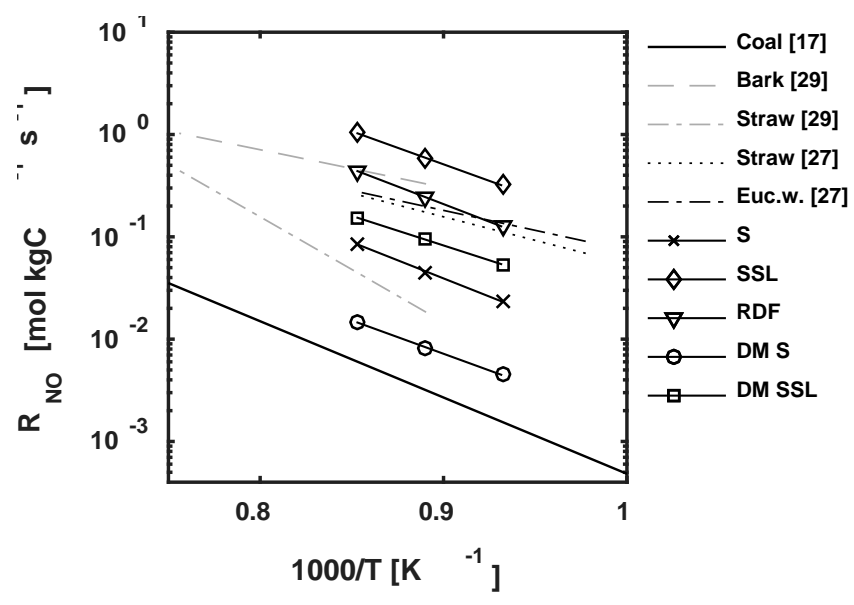


380 Figure 10: Comparison of carbon mass based reaction rates $\left(\mathrm{R}_{\mathrm{NO}}\right)$ obtained in this work with that from 381 other studies. The assumed properties and conditions were $100 \mathrm{~m}^{2} / \mathrm{g}, 1.2 \mathrm{~atm}$ and NO inlet concentration 382 of 500 ppmv.

383 Additionally, the obtained averaged first order kinetic data can be used in modelling studies to evaluate 384 pollutant formation from waste combustion, where interaction between waste char and NO is expected to 385 be prominent, i.e. in fluidized bed combustors.

\section{Conclusions}

388 The reactivities of sewage sludge, refuse derived fuel (RDF), and straw chars towards NO were 389 investigated in a fixed bed reactor at temperatures between 800 and $900^{\circ} \mathrm{C}$ using $\mathrm{NO}$ inlet concentrations 390 from 400 to 1500 ppmv. On a carbon mass basis, the reactivities of sewage sludge and RDF chars were 391 one order of magnitude and six-fold higher than that of straw char, respectively. A demineralization study

392 indicated that the high reactivity could be attributed primarily to the high content of calcium and iron in 393 the waste chars. The initial reactivities correlated well with the $(\mathrm{Ca}+\mathrm{K}+\mathrm{Fe}) / \mathrm{C}$ ratio of the unreacted chars, 394 implying that calcium, potassium, and iron played an important role in char reactivity towards NO.

395 During combustion of straw, RDF, and sewage sludge chars at $800^{\circ} \mathrm{C}$ in $10 \% \mathrm{O}_{2}$ in the fixed bed reactor, 396 the char nitrogen was primarily converted to $\mathrm{NO}$ and $\mathrm{N}_{2}$, and to a lesser extent $\mathrm{N}_{2} \mathrm{O}(<7 \%)$. A 397 mathematical model based on a first order reaction rate expression for NO reduction over char was able 398 to provide a reasonable prediction of the conversion of char nitrogen to NO in the combustion experiments. 399 The high reactivity of waste chars towards NO indicates a potential utilization of the chars in the 400 reduction of NO emission from combustion systems. Moreover, the simplified, concentration averaged, 401 first order rate expression for NO reduction over straw, RDF, and sewage sludge chars can be implemented 402 in large scale simulations of combustion plants. 


\section{Acknowledgements}

405 This project is funded by the Sino-Danish Centre for Education and Research and Technical University

406 of Denmark. In addition, the Academy of Finland financed project (289666) - fate of fuel bound nitrogen 407 in biomass gasification - is acknowledged. 
408 Supplemental material: Supplemental material - Reactivity of sewage sludge, RDF, and straw chars 409 towards NO.docx

410 Table S1: Investigation of the influence of external and internal mass transfer limitations regarding the 411 NO reduction reactions. $-r_{o b s}=\frac{1}{W} F_{N O, i n} X_{N O}$, Maer's criterion $\varphi_{M a e r}=\frac{-r_{o b s} \rho_{C} R_{C}}{k_{g} C_{N O, 0}}<0.15$, relative 412 mass transfer resistance $R e l_{e x t}=\frac{d_{C} /\left(6 k_{g}\right)}{1 /\left(k_{o b s} \rho_{C}\right)}$, Weisz Prater modulus and criterion $\varphi_{W P}=\frac{-r_{o b s} \rho_{C} R_{C}^{2}}{k_{g} C_{N o, 0}} \ll 1$,

413 Thiele modulus: $\varphi=\frac{d_{c}}{6} \cdot\left(\frac{k \cdot \rho_{c}}{D_{\text {eff }}}\right)^{\frac{1}{2}}$, and effectiveness factor: $\eta=\frac{3 \cdot \varphi \cdot \operatorname{coth}(3 \cdot \varphi)-1}{3 \cdot \varphi^{2}}[\mathrm{~S} 1, \mathrm{~S} 3]$ Symbols: $\mathrm{W}$ is the 414 instantaneous mass of carbon, , $\mathrm{F}_{\mathrm{NO}}$,in inlet molar flow of $\mathrm{NO}, \mathrm{X}_{\mathrm{NO}}$ conversion of $\mathrm{NO}$ at given $\mathrm{W}, \rho_{\mathrm{C}}$ is 415 the char density, $\mathrm{d}_{\mathrm{C}}$ and $\mathrm{R}_{\mathrm{C}}$ are char diameter and radius, respectively, $\mathrm{k}_{\mathrm{g}}$ gas film mass transfer constant, $416 \mathrm{k}$ is the first order reaction rate constant, $\mathrm{D}_{\text {eff }}$ is the effective diffusivity.

417 Table S2: Complete ICP-OES of fuels and chars

418 Table S3. Mean residence time $\left(\mathrm{t}_{\mathrm{m}}\right)$ and number of ideal reactors $\mathrm{n}_{\mathrm{CSTR}}$ for each compound.

419 Figure S1: Schematic showing the input of tracer to determine the dispersion subsequent to the packed 420 bed reactor (a), residence time distribution plots for $\mathrm{CO}, \mathrm{CO}_{2}, \mathrm{O}_{2}$ (b), and $\mathrm{NO}$ (c). Repetitions are shown 421 in the distribution plot of NO.

422 Figure S2: $\mathrm{O}_{2}, \mathrm{CO}_{2}, \mathrm{CO}$, and $\mathrm{NO}$ concentration profiles from combustion of $20 \mathrm{mg}$ RDF char at $800^{\circ} \mathrm{C}$ 423 in 10 vol\% $\mathrm{O}_{2}$. The combustion kinetic parameters were fit to the $\mathrm{CO}_{2}$ and $\mathrm{O}_{2}$ profiles, while the $\mathrm{CO}$ was 424 calculated based on a $\mathrm{CO}_{2}$ fraction of 0.97 based on experimental data. The NO concentration plot was 425 calculated from the combustion kinetic parameters and the experimentally obtained reduction rate 426 constant.

427 Figure S3: Repeatability investigation of the NO reduction over char at $800^{\circ} \mathrm{C}$ using an NO inlet 428 concentration of 400 ppmv NO. The subscripts denote the repetition number.

429 Figure S4: Comparison of the predicted NO versus observed NO conversion for sewage sludge and RDF 430 chars at $900^{\circ} \mathrm{C}$ at varying NO inlet concentrations using first order $(n=1)$, fractional order $(n=[0 ; 1[)$, and 
431 random pore model (RPM) rate expressions. For the first order expression the concentration average of 432 the maximum first order rate constant $\left(\mathrm{k}_{\max }\right)$ was used. For the fractional order and RPM expressions, a 433 Maximum Likelihood function was used to minimize the squared sum error between model and 434 experiment at three different concentrations simultaneously. 


\section{References}

436 [1] Seeker WR. Waste Combustion. Proc Combust Inst 1990;23:867-85.

437 [2] Hupa M, Karlström O, Vainio E. Biomass combustion technology development - It is all about 438 chemical details. Proc Combust Inst 2017;36:113-34. doi:10.1016/j.proci.2016.06.152.

439 [3] Frank A, Castaldi MJ. CFD analysis of municipal solid waste combustion using detailed chemical kinetic modelling. Waste Manag Res 2014;32:745-54. doi:10.1177/0734242X14538305.

441 [4] Rogaume T, Auzanneau M, Jabouille F, Goudeau JC, Torero JL. The effects of different airflows on the formation of pollutants during waste incineration. Fuel 2002;81:2277-88. doi:10.1016/S0016-2361(02)00151-5.

444 [5] Rogaume T, Jabouille F, Torero JL. Effect of excess air on grate combustion of solid wastes and on gaseous products. Int J Therm Sci 2009;48:165-73. doi:10.1016/j.ijthermalsci.2008.02.003.

446 [6] Glarborg P, Jensen AD, Johnsson JE. Fuel nitrogen conversion in solid fuel fired systems. Prog Energy Combust Sci 29 2003;29:89-113. doi:10.1016/S0360-1285(02)00031-X.

448 [7] Glarborg P, Miller JA, Ruscic B, Klippenstein SJ. Modelling nitrogen chemistry in combustion. Prog Energy Combust Sci 2018;67:31-68.

[8] Wu X, Song Q, Zhao H, Yao Q. Catalytic Mechanism of Inherent Potassium on the Char-NO Reaction. Energy and Fuels 2015;29:7566-71. doi:10.1021/acs.energyfuels.5b01550.

452 [9] Zhong BJ, Tang H. Catalytic NO reduction at high temperature by de-ashed chars with catalysts. Combust Flame 2007;149:234-43. doi:10.1016/j.combustflame.2006.04.004.

454 [10] Zhao Z, Li W, Li B. Catalytic reduction of NO by coal chars loaded with Ca and Fe in various atmospheres. Fuel 2002;81:1559-64. doi:10.1016/S0016-2361(02)00077-7. 
456 [11] Calo JM, Suuberg EM, Aarna I. The Role of Surface Area in the NO-Carbon Reaction. Energy \& $457 \quad$ Fuels 1999;13:761-2.

458 [12] Chambrion P, Kyotani T, Tomita A. Role of N-containing surface species on NO reduction by 459 carbon. Energy \& Fuels 1998;12:416-21.

460 [13] Karlström O, Perander M, DeMartini N, Brink A, Hupa M. Role of ash on the NO formation during 461 char oxidation of biomass. Fuel 2017;190:274-80. doi:10.1016/j.fuel.2016.11.013.

462 [14] Aho A, DeMartini N, Pranovich A, Krogell J, Kumar N, Eränen K, et al. Pyrolysis of pine and 463 gasification of pine chars - Influence of organically bound metals. Bioresour Technol 2013;128:22464 9. doi:10.1016/j.biortech.2012.10.093.

465 [15] Wu SL, Iisa K. Kinetics of NO Reduction by Black Liquor Char. Energy \& Fuels 1998;12:457-63.

466 [16] Wu X, Song Q, Zhao H, Zhang Z, Zhang L, Yao Q. Influence of mineral transformation on the 467 468 reactivity evolution during rice straw char-NO reaction. Fuel 2013;113:553-9. doi:10.1016/j.fuel.2013.05.102.

[17] Levy JM, Chan LK, Sarofim AF, Beér JM. NO/char reactions at pulverized coal flame conditions. Symp Combust 1981;18:111-20. doi:10.1016/S0082-0784(81)80016-1.

471 [18] Guo F, Hecker WC. Effects of $\mathrm{CaO}$ and burnout on the kinetics of NO reduction by Beulah Zap 472 char. Symp Combust 1996;26:2251-7.

[19] Guo F, Hecker WC. Kinetics of NO reduction by char: Effects of coal rank. Symp Combust 1998;27:3085-92. doi:10.1016/S0082-0784(98)80170-7.

475 [20] Schönenbeck C, Gadiou R, Schwartz D. A kinetic study of the high temperature NO-char reaction. 476 Fuel 2004;83:443-50. doi:10.1016/j.fuel.2003.08.007. 
477 [21] Nikolopoulos A, Malgarinos I, Nikolopoulos N, Grammelis P, Karrelas S, Kakaras E. A decoupled 478 approach for NOx-N2O 3-D CFD modeling in CFB plants. Fuel 2014;115:401-15. 479 doi:10.1016/j.fuel.2013.06.036.

480 [22] Zhou H, Jensen AD, Glarborg P, Jensen PA, Kavaliauskas A. Numerical modeling of straw 481 combustion in a fixed bed. Fuel 2005;84:389-403. doi:10.1016/j.fuel.2004.09.020.

482

483

484

485

486

487

488

489

490

491

492

493

494

495

496

497

498

[23] Gunn DJ. On axial dispersion in fixed beds. Chem Eng Process 1993;32:333-8. doi:10.1016/02552701(93)80020-H.

[24] Fjellerup J, Henriksen U, Jensen AD, Jensen PA, Glarborg P. Heat transfer in a fixed bed of straw char. Energy and Fuels 2003;17:1251-8. doi:10.1021/ef030036n.

[25] Sin G, Gernaey K. Data handling and parameter estimation. In: Van Loosdrecht MCM, Nielsen PH, Lopez-Vazquez DM, Brdjanovic D, editors. Exp. Methods Wastewater Treat., London: IWA Publishing; 2016, p. 201-34.

[26] Karlström O, Brink A, Hupa M, Tognotti L. Multivariable optimization of reaction order and kinetic parameters for high temperature oxidation of 10 bituminous coal chars. Combust Flame 2011;158:2056-63. doi:10.1016/j.combustflame.2011.03.003.

[27] Garijo EG, Jensen AD, Glarborg P. Kinetic Study of NO Reduction over Biomass Char under Dynamic Conditions. Energy \& Fuels 2003;17:1429-36.

[28] Garijo EG, Jensen AD, Glarborg P. Reactivity of coal char in reducing NO. Combust Flame 2004;136:249-53. doi:10.1016/j.combustflame.2003.09.007.

[29] Zhao K, Glarborg P, Jensen AD. NO Reduction over Biomass and Coal Char during Simultaneous Combustion. Energy \& Fuels 2013;27:7817-26.

[30] Karlström O, Brink A, Hupa M. Time dependent production of NO from combustion of large 
biomass char particles. Fuel 2013;103:524-32. doi:10.1016/j.fuel.2012.06.030.

500 [31] Winter F, Wartha C, Löffler G, Hofbauer $\mathrm{H}$. The $\mathrm{NO}$ and $\mathrm{N}_{2} \mathrm{O}$ formation mechanism during devolatilization and char combustion under fluidized-bed conditions. Symp Combust

[32] Molina A, Eddings EG, Pershing DW, Sarofim AF. Char nitrogen conversion: implications to emissions from coal-fired utility boilers. Prog Energy Combust Sci 2000;26:507-31.

505

506

507

508

509 1996;26:3325-34. doi:10.1016/S0082-0784(96)80180-9.

[33] Molina A, Sarofim AF, Ren W, Lu J, Yue G, Beér JM, et al. Effect of boundary layer reactions on the conversion of CHAR-N to NO, N 2 O, and HCN at fluidized-bed combustion conditions. Combust Sci Technol 2002;174:43-71. doi:10.1080/713712945.

[34] Johnsson JE. Formation and reduction of nitrogen oxides in fluidized-bed combustion. Fuel 1994;73:1398-415.

[35] Chambrion P, Kyotani T, Tomita A. C-NO reaction in the presence of $\mathrm{O}_{2}$. Symp Combust 1998;27:3053-9.

[36] Sørensen CO, Johnsson JE, Jensen A. Reduction of NO over wheat straw char. Energy and Fuels 2001;15:1359-68. doi:10.1021/ef000223a.

[37] Dong L, Gao S, Song W, Xu G. Experimental study of NO reduction over biomass char. Fuel Process Technol 2007;88:707-15. doi:10.1016/j.fuproc.2007.02.005.

[38] Guerrero M, Millera Á, Alzueta MU, Bilbao R. Experimental and Kinetic Study at High Temperatures of the NO Reduction over Eucalyptus Char Produced at Different Heating Rates. Energy \& Fuels 2011;25:1024-33.

[39] Johnsson JE, Jensen A. Effective diffusion coefficients in coal chars. Proc Combust Inst 2000;28:2353-9. doi:10.1016/S0082-0784(00)80647-5. 
521 [40] Barišić V, Kilpinen P, Hupa M. Comparison of the catalytic activity of bed materials from the 522 combustion of biomass and waste fuels in a circulating fluidized bed boiler toward NO reduction 523 by CO. Energy and Fuels 2006;20:1925-32. doi:10.1021/ef060094j.

524 [41] De Soete GG. Heterogeneous $\mathrm{N}_{2} \mathrm{O}$ and $\mathrm{NO}$ formation from bound nitrogen atoms during coal char 525 combustion. Symp Combust 1991;23:1257-64. doi:10.1016/S0082-0784(06)80388-7.

526 [42] Jones JM, Patterson PM, Pourkashanian M, Williams a. Approaches to Modelling Heterogenous 527 Char NO Formation/Destruction during Pulverised Coal Combustion. Carbon N Y 1999;37:1545$528 \quad 52$.

529 [43] Bhatia SK, Perlmutter DD. A Rondom Pore Model for Fluid-Solid Reactions:1. Isothermal, Kinetic $530 \quad$ Control. AIChE J 1980;26:379-86. 